\title{
Learning a Local Language at School in Indonesian Setting
}

\author{
Nurlaksana Eko Rusminto \\ Language Education, Faculty of Education Universitas Lampung, Indonesia \\ Farida Ariyani \\ Language Education, Faculty of Education Universitas Lampung, Indonesia \\ Ag. Bambang Setiyadi \\ English Department, Faculty of Education Universitas Lampung, Indonesia
}

\begin{abstract}
This study attempted to identify how attitude and motivation and the success in language achievement are correlated. The subjects of this study consisted 73 students who had been learning Lampungese as a local language in Indonesia. The data on the attitude and motivation was arranged in a Likert- Style format and the data on the success in language learning was collected through a test consisting four language skills. The data collected from the questionnaires were analyzed to measure internal consistency of hypothesized scales by using item-to scale coefficient. To determine how the variabels were correlated, correlation analyses were undertaken. The result shows that students' attitude predicted motivation, and, in turn, their motivation predicted their language performance; it may be interpreted that attitude predicts motivation through the mediation of motivation.
\end{abstract}

Index Terms — language attitude, local language, motivation, language achievement

\section{INTRODUCTION}

Many studies on attitude have referred to the findings of Thurstone's study conducted in 1946. In his study, he defines attitude as the intensity of positive or negative affect for or against a psychological object. He further explains that a psychological object is any symbol, person, phrase, slogan, or idea towards which people can differ as regards positive or negative affect (Kiesler et al., 1969, p. 2). A definition proposed by Shaw and Wright (1967, p. 10) is that attitude is a relatively enduring system of affective, evaluative reactions based upon and reflecting concepts or beliefs which have been learned about the characteristics of a social object or class of social objects. The latter definition implies that attitudes are not innate, and they are learned (Shaw and Wright, 1967). They are regarded as products of social structure. This is consistent with Campbell (cited in Lemon, 1973, p. 8), who believes that attitude is a syndrome of response consistency with regard to a set of social objects. By identifying attitude of language learners, it is expected that teachers may make their students to have positive attitude to the target language in order that the learners learn thelanguage optimally.

In order to identify the attitude of the learners, the attitude should be measured and it is quite possible that attitudes towards an object are not overtly expressed but still measurable. It seems that attitudes become behaviorally manifested when people do not expect anything by pretending. Baker (1992) states that attitude is a hypothetical construct used to explain the direction and persistence of human behavior. He explains that attitudes are latent and hidden though they can be used to predict behavior. They cannot be directly measured. From the above definitions, it can be concluded that attitude is a relatively constant system of evaluative processes towards an object(s) based on what individuals have learned in previous settings. The affective evaluation towards an object may range along a continuum from positive values to negative values as stated by Fishbein and Ajzen (1975). Zero attitudes are considered as no attitude towards the attitude object or an ambivalent attitude (Shaw and Wright, 1967). Even though attitudes are relatively constant in individuals, attitudes have been learned. Since they are learned, they may be changed by further learning (Lemon, 1973). This is one of the reasons why identifying the attitude to the target language is important in teaching the language.

Attitudinal behaviour can be divided into three components: cognitive, affective, and conative elements (Lemon, 1973; Baker, 1992; Els et al., 1984). The cognitive component of attitude refers to the way in which individuals perceive and conceptualize an attitude object. It represents an individual's belief about the attitude object. The affective component refers to the feeling towards the attitude object. It is said that individuals may differ markedly in the characteristics they ascribe to an attitude object, but they may be identical to each other in the degree of positive or negative feeling they manifest towards it (Lemon, 1973). The conative component, which is also called action component (Baker, 1992, p.13), is concerned with an individual's intention to behave in certain ways with regard to the attitude object, which is called readiness for action. 
It is said that the belief about an attitude object is different from the opinion about the object. Thurstone (cited in Lemon, 1973) states that an opinion is simply a manifestation of an attitude, and that opinion can, therefore, be used to diagnose the underlying attitude predisposition. Opinion is defined as an overt belief without an affective reaction while attitudes contain affective reaction (Baker, 1992; and Summers, 1969). However, opinion is not always consistent to attitude. For example, a man may be a liar for reasons of courtesy, especially in those situations in which frank expression of attitude may not be well-received (Summers, 1969).

The role of attitude and motivation in language learning

So far, the discussion relates to attitude in general. Baker (1992) discusses attitude more specifically in terms of language. Language attitude is considered very important to language teaching since policies on language can flourish or fail according to the language attitudes of the community. He agrees that there are two kinds of language attitude: instrumental attitude and integrative attitude. Instrumental attitude is mostly self-oriented and individualistic, e.g. vocational reason, status, achievement, personal success and survival, while integrative attitude to a language is mostly a social and interpersonal orientation and may concern attachment to, or identification with a language group and its cultural activities (p. 32).

Baker (1992) interchanges the term attitude with motivation. It seems that the interchange is influenced by Gardner and Lambert. The term integrative and instrumental, which is used to classify attitude, is commonly used to classify motivation (Gardner and Lambert, 1972). Also, there seems to be some disagreement about the terms of integrative and instrumental motivation in classifying the reasons for learning a foreign language. Various researchers might classify reasons for learning a foreign language differently (Spolsky, 1988). The term "integration" seems to have resulted from the situation in Montreal, where integration is an important issue for English speaking people and French speaking people. However, it is important to note that Gardner and Lambert found that while aptitude for language is one factor in the equation why some learn quickly and others slowly, attitude or motivation to learn a language was found to be independent of language aptitude. Students with higher ability or greater aptitude were not the only ones with favourable attitudes, nor were they guaranteed to succeed in learning a second language (cited in Baker 1992, p. 33).

Although the term attitude and the term motivation refer to similar ideas, Gardner et al. (1993) seem to have differentiated attitude from motivation. Their study shows that success in mastering another language also depends on motivation, language attitudes and other individual differences. Gardner and Lambert (1972) further explain that the learner's motivation for language study will be determined by his/her attitude and readiness to identify and by his/her orientation to the whole process of learning (1979).

The discussion of the role of attitude and motivation in second language learning seems not to be final. Els et al. (1984) states that Gardner and Oller have redefined the distinction between attitude and motivation. Attitudes are considered to be directly related to motivation and viewed as motivational support and not as factors which directly affect learning process. It also implies that motivation directly effects on L2 learning. Motivation to learn a language is not only determined by attitudes, but also by other factors, such as the desire to please teachers or the promise of a reward. Els et al. (1984) further explains that a learner who is instrumentally motivated does not necessarily have positive attitudes towards the target language group. Kuhlemeier et al. (1996, p.500) assumed a strong relationship between attitude and achievement but the empirical data in their study did not justify the assumption. Their study, which involved secondary school students of the first German language instruction in Dutch Secondary Education, suggests that at the end of the school year the attitude and achievement correlated as weakly as at the beginning of school year. Further, negative relationships between attitude and achievement were found in a study by Svanes (1988). None of three groups from different cultural backgrounds: Western, Middle East and Africa, and Asia, who were the subjects of his study, revealed a positive relationship between achievement and attitude. The two studies explored the relationship between attitudes and language achievement.

Some other studies have also been conducted to investigate the role of different types of motivation. Different from the studies that have been discussed, which studied motivation from general perpectives (Olshtain et al., 1990; and Oxford \& Nyikos, 1989), some studies classified motivation under two types, namely instrumental motivation and integrative motivation (Gardner \& Lambert, 1972). Instrumental motivation is considered as desire to meet practical reasons and integrative motivation is considered as desire to be as members of the native speakers (Krashen, 1988). The integrative motivation is often believed to be superior to the intrumental motivation (Gardner, 1985). Grouping motivation inder the two types is commonly used in learning another language.

It seems more reasonable to classify motivation as intrinsic and extrinsic (Ramage, 1990). Therefore, in this study, students' motivation was classified based on the reasons for learning English, namely whether the reason (s) are internal to the behavior (intrinsic) or external to the behavior (extrinsic). Ramage (1990) investigated factors that influence the decision to continue or discontinue foreign language study and provides data that intrinsic motivation emerged as a stronger contributor than did extrinsic motivation (p.207-208). The students' motivation was also measured based on the intensity of the motivation and it was measured by identifying how high or low the intensity of their motivation was.

Attitudes that are probably related to motivation to learn a foreign language are attitudes towards the language, the teacher, and the course (Setiyadi \& Sukirlan, 2016). Baker (1992) states that language attitude is an umbrella term, under which resides a variety of specific terms, such as attitude to language groups, to language lesson, and to the uses of specific language. The present study was aimed to identify the attitude to an indigenious language, the teaching of the 
the indigenious language and the speakers of the language. The study is expected to solve a problem why the result of the teaching of the indigenous language at school in Indonesia is still far from expected.

The discussion and investigation of attitude is challenging. The variation in findings seems to have been due to different concepts and definitions of attitude and motivation and the relationships of the two variables with language proficiency. It seems that there is a need to identify the role of attitude and motivation in learning a local language. The objective of this present study is to identify how attitude to a local language is correlated with students' motivation and linguistic proficiency. The findings of the present study will response on how attitude to a local language, motivation and success in learning a local language are intercorrelated, and the findings of this study is also expected to provide teachers with an idea how they have to deal with the language attitude of the students in learning a local language, their motivation in learning the local language, in order for the students to have better results in learning the local language.

\section{Methodology}

The subjects of the study were 73 students who had been learning Lampungese as a local language, which is one of the indigenous languages in Indonesia. The data were collected through a questionnaire, which were developed to measure the attitude to the language, attitude to the teaching of the language and the attitude to the speakers of the language. This questionnaire consists of 30 items (Widodo, Ariyani \& Setiyadi, 2017). The responses of strongly agree got 5 and those of strongly disagree got 1 .

The questionnaire which was meant to assess motivation consisted of 40 items (Widodo, Ariyani \& Setiyadi, 2017). In the questionnaire of motivation, students were provided with statements with three possible answers which were arranged in an ordinal variaable. The scores of the choices are 1 for the lowest motivation and 3 for the highest motivated behavior. The items are either negatively worded or positively worded. Some items of the questionnaire to asses motivation was theories of motivation and some other items were adapted from Gardner (1974). The two questionnaires were given in in the national language, Indonesian.

Language proficiency was measured to assess the language proficiency of the local language. The test consists of the four parts of language skills, namely: listening, speaking, reading and writing. Each part has 10 items. The total score for each section is 25 with no penalty for wrong answers. The total score ranges from 0 to 100 .

The data collected from the questionnaires were analysed to measure internal consistency of hypothesized scales by using item-to scale coefficient. This was done to obtain an indicator of the scales' unidimensionality by determining if the responses to a particular item reflected the pattern of responses on other items (de Vaus, 1985, pp. 88-89). If it did not, it was assumed that the item was measuring something different from the other items and it was dropped from the scale. The analysis was conducted by using the Cronbach alpha coefficient. The alpha ranges between 0 and 1 , the higher the alpha, the more reliable is the questionnaire.

\section{RESULT}

To measure the internal consistency of the hypothesized scales of the questionnaire of language attitude and motivation, Cronbach Alpha coefficients were computed for each scale. Table 1 provides evidence that the scales of attitude and motivation have high alpha values. All the scales in this study were internally consistent; therefore, the criteria on internal consistency of the constructs were met in this analysis. In general, the items developed in the present study had high correlation with their constructs so that the items of the two questionnaires were considered valid, as shown on Table 2 .

TABLE 1

RELIABILITY OF THE MEASURES

\begin{tabular}{|l|l|l|}
\hline Scales & Items & Cronbach's alpha \\
\hline Attitude to Lampungese language & 10 items & .80 \\
\hline Attitude to the learning of Lampungese language & 10 items & .79 \\
\hline Attitude to Lampungese speakers & 10 items & .85 \\
\hline Desire to learning Lampungese language & 20 items & .88 \\
\hline Intensity in learning Lampungese language & 20 items & .80 \\
\hline
\end{tabular}

TABLE 2

VALIDITY OF EACH ITEM WITH THE CONSTRUSTS

\begin{tabular}{|l|l|}
\hline Constructs & VALIDITY OF EACH ITEM WITH THE CONSTRUSTS \\
\hline Attitude to the local language & $1) 0,706$ 2)0,702 3)0,730 4)0,740 5)0,802 6)0,811 7)0,932 8)0,718 9) 0,760 10) 0,793 \\
\hline Attitude to the learning of the local language & $11) 0,764$ 12)0,716 13)0,729 14)0,768 15)0,755 16)0,811 17)0,799 18)0,844 19)0,630 20) \\
& 0,806 \\
\hline Attitude to the native speakers & $21) 0,703$ 22)0,856 23)0,664 24)0,773 25)0,667 26)0,877 27)0,857 28)0,888 29)0,745 \\
& $30) 0,777$ \\
\hline Desire to learning a language & $10,8062) 0,7723) 0,7354) 0,8405) 0,7026) 0,808$ 7)0,832 8)0,818 9)0,860 10)0,893 11)0,784 \\
\hline Intensity in learning a language & $12) 0,77613) 0,62914) 0,868,15) 0,70516) 0,877$ 17)0,711 18)0,644 19)0,650 20) 0,776 \\
\hline & $21) 0,80322) 0,80523) 0,87424) 0,673$ 5)0,743 26) 0,742 27)0,770 28)0.777 29)0,738 30)0,709 \\
\hline
\end{tabular}


To determine how attitude correlate with motivation and language proficiency, correlation analyses were undertaken. As can be seen from Table 3 the attitude were statistically significantly correlated with motivation but not significantly correlated with language proficiency. Even though attitude was significantly correlated with language proficiency, motivation was significantly correlated with language proficience. This suggests that attitude affects learners' motivation and their motivation has positive effects on language performance.

TABLE 3

CORRELATIONS OF THE VARIABLES

\begin{tabular}{|c|c|c|c|c|c|c|c|c|}
\hline & (a) & (a1) & $(\mathrm{a} 2)$ & (a3) & (b) & (b1) & (b2) & $\mathrm{c}$ \\
\hline Language attitude (a) & - & $.77 * *$ & $.70 *$ & .43 & $.69 *$ & $53 * *$ & $74 *$ & 50 \\
\hline Attitude to the local language (a1) & & - & $.88 * *$ & .72 & $.66^{* * *}$ & $.73 * *$ & $.55^{*}$ & .45 \\
\hline $\begin{array}{l}\text { Attitude to the learning of the local } \\
\text { language (a2) }\end{array}$ & & & - & .25 & $.75^{* *}$ & $.71 *$ & $.63^{*}$ & .52 \\
\hline Attitude to the native speakers (a3) & & & & - & .45 & .25 & .56 & .77 \\
\hline Motivation (b) & & & & & - & $.55^{*}$ & $.88^{* *}$ & $.71 * *$ \\
\hline Desire to learning a language (b1) & & & & & & - & $.44 * *$ & $.62 * *$ \\
\hline Desire to learning a language (b2) & & & & & & & - & $.76^{* *}$ \\
\hline Language performance (c) & & & & & & & & - \\
\hline
\end{tabular}

\section{DISCUSSION}

The empirical data provided in this study shows that the attitude of the students toward Lampungese language as a local language was significantly correlated with their motivation in learning the language while motivation was significantly correlated with language performance. The significant correlation between attitude to the local language and the learning of the local language indicates that attitude and motivation have close relationship. It implies that attitude is the cause and motivation is the effect. Contention is based on the theories that students' attitudes will influence their effort in learning a foreign language since the effort is correlated with actions (Mantle-Bromley, 1995). The actions refers intensity and intentions refers to desire (intention) in learning the local language. Thus, attitudes, particularly attitude to the local language and the learning of the local language, affect motivation in learning the language. This supports an assumption proposed by Gardner and MacIntyre (1993) that motivation mediates any relation between language attitudes and language achievement.

The findings show that attitudes to native speakers of the local language are not significantly correlated with either motivation or the components of motivation. This can suggest that although attitudes to the speakers of a language will affect motivation in learning the language of the speakers whenever the students wish to integrate themselves and get along with the speakers, this condition seems not to happen, if not impossiblee. In Indonesia learning the local language is acquired more as an instrument to have better scores at schools. This may therefore explain why attitude to English and learning English is more correlated with motivation than is attitudes to native speakers of the local language.

That motivation plays a great role in language learning is not questionable; many studies have been conducted that support this statement (Setiyadi, 2016; Setiyadi, Mahpul, Sukirlan \& Rahman, 2016). The findings of the present study indicate that the more motivated students have better language performance. This is in line with a study conducted by Wen and Johnson (1997), which provides evidence that motivation, with other L2 learner variables, has a direct effect on English proficiency. The empirical evidence in their study, whose participants were university students in China, suggests that differences in motivation lead to differences in language proficiency. A study by Olshtain, Shohamy, Kemp, and Chatow (1990), which involved Hebrew-speaking children in the Israeli school system, also suggests that the correlation of motivation (and attitude) and achievement in English is strong and supports the argument that motivation affects achievement.

The relationship among attitude, motivation and language performance indicate that students' attitude predicted motivation, and, in turn, their motivation predicted their language performance. Therefore, it may be interpreted that attitude predicts motivation through the mediation of motivation.

\section{ACKNOWLEDGMENTS}

We would like to thank the students for helping to collect the data. The study was financially supported by Universitas Lampung, the Ministry of Research, Technology and Higher Education of Indonesia.

\section{APPENDix A: ATtitude QuestionnAire}

Following are a number of statements with which some people agree and others disagree. There are no right or wrong answers since many people have different opinions. We would like you to indicate your opinions about each statement by ticking the alternative below which best indicates the extent to which you agree or disagree with that statement. 


\begin{tabular}{|c|c|c|c|c|c|c|}
\hline No & Statements & $\begin{array}{l}\text { Strongly } \\
\text { agree }\end{array}$ & Agree & Can't decide & Disagree & $\begin{array}{l}\text { Strongly } \\
\text { disagree }\end{array}$ \\
\hline 1 & $\begin{array}{l}\text { Lampungese is necessary in the era of } \\
\text { globalization }\end{array}$ & & & & & \\
\hline 2 & $\begin{array}{l}\text { Lampungese is a language with standard } \\
\text { rule }\end{array}$ & & & & & \\
\hline 3 & $\begin{array}{l}\text { In Indonesia the use of Lampungese } \\
\text { should be restricted. }\end{array}$ & & & & & \\
\hline 4 & $\begin{array}{l}\text { Lampungese is a popular language in } \\
\text { Indonesia }\end{array}$ & & & & & \\
\hline 5 & $\begin{array}{l}\text { Television programs shown in } \\
\text { Lampungese in Indonesia must be } \\
\text { translated into Indonesian }\end{array}$ & & & & & \\
\hline 6 & $\begin{array}{l}\text { Lampungese is less important than other } \\
\text { foreign languages for Indonesians }\end{array}$ & & & & & \\
\hline 7 & $\begin{array}{l}\text { Lampungese is a very complicated } \\
\text { language }\end{array}$ & & & & & \\
\hline 8 & $\begin{array}{l}\text { Lampungese is a language of educated } \\
\text { people }\end{array}$ & & & & & \\
\hline 9 & $\begin{array}{l}\text { Listening to Lampungese songs is } \\
\text { disgusting }\end{array}$ & & & & & \\
\hline 10 & Lampungese pronunciation is beautiful & & & & & \\
\hline 11 & $\begin{array}{l}\text { Learning Lampungese is obligatory in this } \\
\text { province }\end{array}$ & & & & & \\
\hline 12 & $\begin{array}{l}\text { If I have children, I would like them also } \\
\text { to learn Lampungese out of school hours }\end{array}$ & & & & & \\
\hline 13 & $\begin{array}{l}\text { I prefer to be taught Lampungese at all } \\
\text { school levels. }\end{array}$ & & & & & \\
\hline 14 & Learning Lampungese is interesting. & & & & & \\
\hline 15 & Learning Lampungese makes me happy. & & & & & \\
\hline 16 & $\begin{array}{l}\text { I would rather spend my time on another } \\
\text { language (if any) than Lampungese. }\end{array}$ & & & & & \\
\hline 17 & Learning Lampungese is dull & & & & & \\
\hline 18 & $\begin{array}{l}\text { Lampungese class should be an optional } \\
\text { subject }\end{array}$ & & & & & \\
\hline 19 & Lampungese is a language worth learning & & & & & \\
\hline 20 & $\begin{array}{l}\text { Learning Lampungese can influence our } \\
\text { way of life based on our country }\end{array}$ & & & & & \\
\hline 21 & $\begin{array}{l}\text { Native speakers of Lampungese are } \\
\text { friendly }\end{array}$ & & & & & \\
\hline 22 & $\begin{array}{l}\text { Native speakers of Lampungese are } \\
\text { generally well educated }\end{array}$ & & & & & \\
\hline 23 & $\begin{array}{l}\text { Native speakers of Lampungese feel too } \\
\text { superior to other people }\end{array}$ & & & & & \\
\hline 24 & $\begin{array}{l}\text { Native speakers of Lampungese are money } \\
\text { oriented }\end{array}$ & & & & & \\
\hline 25 & $\begin{array}{l}\text { Native speakers of Lampungese are } \\
\text { arrogant }\end{array}$ & & & & & \\
\hline 26 & $\begin{array}{l}\text { Native speakers of Lampungese tend to } \\
\text { intervene another country's domestic } \\
\text { affairs }\end{array}$ & & & & & \\
\hline 27 & $\begin{array}{l}\text { Native speakers of Lampungese are } \\
\text { trustworthy }\end{array}$ & & & & & \\
\hline 28 & $\begin{array}{l}\text { Native speakers of Lampungese are hard } \\
\text { working }\end{array}$ & & & & & \\
\hline 29 & $\begin{array}{l}\text { Native speakers of Lampungese are } \\
\text { considerate of the feeling of others }\end{array}$ & & & & & \\
\hline 30 & Native speakers of Lampungese are selfish & & & & & \\
\hline
\end{tabular}

\section{APPENDIX B. Motivation QuestionNAIRE}

Please answer each of the following items by circling the letter of the alternatives which appear to most applicable to you. We hope you to be as accurate as possible since the success of this investigation depends on it.

1. Why do I learn Lampungese? I can honestly say that I

a. try to kill my spare time.

b. am suggested by somebody else to join.

c. really try to learn Lampungese.

2. If my Lampungese teacher wants someone to do an extra Lampungese assignment, I will

a. definitely volunteer

b. only do it if he/she asks me directly 
c. definitely not volunteer

3. When I hear Lampungese songs on the radio, I

a. change the station.

b. prefer to listen to the music, paying attention only to the easy words.

c. prefer to listen carefully and try to understand all the words.

4. If I have Lampungese homework, I

a. just skim over it.

b. put some effort into it, but not as much as I could.

c. work very carefully, making sure I understand everything.

5. When I see directions written in Lampungese, I

a. read them carefully and try to understand.

b. read them over, but give up if it gets difficult.

c. look for the Indonesian translation.

6. If I have a problem in understanding something while I am learning Lampungese, I

a. just forget about it.

b. only seek help just before the exam.

c. immediately ask the teacher for help.

7. I actively think about what I have learned in the Lampungese course
a. very frequently
b. once in a while
c. hardly ever

8. When I am in the Lampungese discussion, I
a. never say anything.
b. speak once a while.
c. speak quite often.

9. Outside of class I read Lampungese books and magazines.
a. quite often
b. once a while
c. never

10. After I get my Lampungese assignment back, I

a. always rewrite them, correcting my mistakes.

b. look them over, but I don't bother correcting mistakes.

c. just throw them in my bag and forget it.

11. If an Lampungese course is offered, I will
a. not enroll in the course.
b. enroll if it is free.
c. definitely enroll.

12. If I have an opportunity to speak Lampungese outside class, I will
a. speak it most the time if it is possible.
b. speak it occasionally if it is necessary.
c. never speak it.

13. During the Lampungese class, I would like
a. to have only Lampungese spoken.
b. to have a combination of Indonesian and Lampungese spoken.
c. to have Indonesian spoken as much as possible.

14. If I had opportunity to meet Lampungese speaking families, I would
a. not go.
b. go only if I had nothing to do.
c. definitely go.

15. If I had a choice, I would like to take
a. a Lampungese class only.
b. a Lampungese and another local language class.
c. another local language class.

16. If there were a Lampungese speaking club here, I would
a. try to attend the meetings as often as possible.
b. attend the meeting only once a while.
c. not join.

17. If I knew enough Lampungese, I would watch Lampungese Television programs
a. as often as possible.
b. sometimes. 
c. never.

18. If I had opportunity and knew enough Lampungese, I would read Lampungese books and magazines
a. never.
b. not very often.
c. as often as possible.

19. After I finish my Lampungese class, I will probably
a. make no attempt to remember the Lampungese I have learned.
b. try to use the Lampungese that I am very sure of.
c. try to use Lampungese as much as possible.

20. If there were a Lampungese television station, I would
a. never watch it.
b. turn it on occasionally.
c. try to watch it often.

21. Why do I learn Lampungese? I can honestly say that I
a. try to kill my spare time.
b. am suggested by somebody else to join.
c. really try to learn English.

22. If my Lampungese teacher wants someone to do an extra Lampungese assignment, I will
a. definitely volunteer
b. only do it if he/she asks me directly
c. definitely not volunteer

23. When I hear Lampungese songs on the radio, I
a. change the station.
b. prefer to listen to the music, paying attention only to the easy words.
c. prefer to listen carefully and try to understand all the words.

24. If I have Lampungese homework, I
a. just skim over it.
b. put some effort into it, but not as much as I could.
c. work very carefully, making sure I understand everything.

25. When I see directions written in Lampungese, I
a. read them carefully and try to understand.
b. read them over, but give up if it gets difficult.
c. look for the Indonesian translation.

26. If I have a problem in understanding something while I am learning Lampungese, I:
a. just forget about it.
b. only seek help just before the exam.
c. immediately ask the teacher for help.

27. I actively think about what I have learned in the Lampungese course...
a. very frequently
b. once in a while
c. hardly ever

28. When I am in the Lampungese discussion, I
a. never say anything.
b. speak once a while.
c. speak quite often.

29. Outside of class I read Lampungese books and magazines.
a. quite often
b. once a while
c. never

30. After I get my Lampungese assignment back, I
a. always rewrite them, correcting my mistakes.
b. look them over, but I don't bother correcting mistakes.
c. just throw them in my bag and forget it.

31. If a Lampungese course is offered, I will
a. not enroll in the course.
b. enroll if it is free.
c. definitely enroll.

32. If I have an opportunity to speak Lampungese outside class, I will
a. speak it most the time if it is possible.
b. speak it occasionally if it is necessary. 
c. never speak it.

33. During the Lampungese class, I would like

a. to have only English spoken.

b. to have a combination of Indonesian and Indonesian spoken.

c. to have Indonesian spoken as much as possible.

34. If I had opportunity to meet Lampungese speaking families, I would
a. not go.
b. go only if I had nothing to do.
c. definitely go.

35. If I had a choice, I would like to take
a. a Lampungese class only.
b. a Lampungese and another foreign language class.
c. another local language class.

36. If there were a Lampungese speaking club here, I would
a. try to attend the meetings as often as possible.
b. attend the meeting only once a while.
c. not join.

37. If I knew enough Lampungese, I would watch Lampungese Television programs
a. as often as possible.
b. sometimes.
c. never.

38. If I had opportunity and knew enough Lampungese, I would read Lampungese books and magazines
a. never.
b. not very often.
c. as often as possible.

39. After I finish my Lampungese class, I will probably
a. make no attempt to remember the Lampungese I have learned.
b. try to use the Lampungese that I am very sure of.
c. try to use Lampungese as much as possible.

40. If there were a Lampungese television station, I would:
a. never watch it.
b. turn it on occasionally.
c. try to watch it often.

\section{REFERENCES}

[1] Baker, C. (1992). Attitudes and language. Adelaide: Multilingual Matters Ltd.

[2] Ely, C. M. (1986). Language learning motivation: a descriptive and causal analysis. The Modern Language Journal, 70, I, 2835.

[3] Els, T., Bongaerts, E, Guus, O.C. \& Janssen-van D. (1984). Applied linguistics and the learning and teaching of foreign languages. Victoria: Edward Arnold Pty.

[4] Fishbein, M \& Ajzen, I. (1975). Belief, attitude, intention and behavior: an introduction theory and research. Massachusetts: Addison-Wesley Publishing Company.

[5] Gardner, R.C. \& Lambert W.E. (1972). Attitudes and motivation in second language learning. Massachusetts: Newbury House Publisher.

[6] Gardner, R.C. \& MacIntyre, P.D. (1993). A Student's contributions to second-language learning. Part II: affective variables. Language Teaching, 26, 1-11.

[7] Johnson, E. S. (1980). Assessment of learning in the selection concept-learning task. Journal of Educational Psychology, 72, 6, 821-829.

[8] Kiesler, C. A., Collins, B.A. \& Miller, N. (1969). Attitude change: a critical analysis of theoritical approaches. New York: John Wiley \&sons, Inc.

[9] Krashen, S. D. (1988). Second language acquisition and second language learning. New York: Prentice Hall International Ltd.

[10] Lemon, N. (1973). Attitudes and their measurement. London: B.T. Batsford Ltd.

[11] Mantle-Bromley, C. (1995). Positive attitude and realistic beliefs: links to proficiency. The Modern language Journal, 79, iii, 372-386.

[12] Olshtain, E, Shohamy, E, Kemp, J \& Chatow, R. (1990). Factors predicting success in EFL among culturally different learners. Language Learning, 40, 1, 23-44.

[13] Oxford, R \& Nyikos, M. (1989). Variables affecting choice of language learning strategies by university students. The Modern Language Journal, 73, iii, 291-300.

[14] Oxford, R \& Shearin, J. (1994). Language learning motivation: expanding the theoretical framework. The Modern Language Journal, 78, I, 12-28.

[15] Ramage, K. (1990). Motivational factors and persistence in foreign language study. Language Learning, 40:2, 189-219.

[16] Setiyadi, A.B. (2016). Language Learning Strategy Questionnaire. Yogyakarta, Indonesia: Graha Ilmu. 
[17] Setiyadi, A.B. \& Sukirlan, M. (2016). Language attitude and motivation of the Islamic school students: How do Madrasa students of the academic year 2013 -2014 in Indonesia perceive English, English teaching and learning and native speakers of English? Pertanika Journal of Social Science and Humanities, 23, 1, 329-348.

[18] Setiyadi, A.B., Mahpul, Sukirlan, M. \& Rahman, B. (2016). Language motivation, metacognitive strategies and language performance: a cause and effect correlation. International Journal of Applied Linguistics and English Literature, 5, 7, 40-47.

[19] Shaw, M. E. \& Wright, J. M. (1967). Scales of the measurement of attitudes. Sydney: Mc Graw-Hill Book Company.

[20] Spolsky, B. (1988). Conditions for second language learning. Melbourne: Oxford University Press.

[21] Sung, H. \& Padilla, A. (1998). Student motivation, parental attitudes, and involvement in the learning of Asian languages in elementary and secondary Schools. The Modern Language Journal, 82, ii, 205-216.

[22] Summers, G. F. (1969). Attitude measurement (second edition). Chicago: Rand Mc. Nally.

[23] Svanes, B. (1988). Attitudes and cultural distance in second language acquisition. Applied Linguistics, 9, 4, 357-371.

[24] Wen, Q \& Johnson, K. R. (1997). L2 learner variables and English achievement: a study of tertiary-level English majors in China. Applied Linguistics, 18, 1, 27-48.

[25] Widodo, M, Ariyani, F., \& Setiyadi, A.B. (2017). Attitude and motivation in learning a local language. Theory and Practice in Language Studies, 8, 1, 105-112.

Nurlaksana Eko Rusminto is a lecturer in the Department of Language Education, Faculty of Education, Lampung University. His researches mainly include language teaching and linguistics. He has published several books and papers.

Farida Ariyani is a lecturer in the Department of Language Education. She has taught Lampungese courses at the Faculty of Education, Lampung University, Indonesia. Her research interests include second language acquisition, communication strategies as well as intercultural communication

Ag. Bambang Setiyadi teaches courses in language teaching methodology and research methodology at the Department of English Language of Lampung University, Indonesia. He has presented and published nationally and internationally on issues related to language teaching and learning. 